\title{
OBSERVASI SISTEMATIK PADA PEMBELAJARAN AQIDAH AKHLAQ
}

\author{
Ismanto dan Eka Fery Irawan
}

STAIN Kudus Jawa Tengah Indonesia

ismanto_07@yahoo.co.id

ekaferirawan@gmail.com

\begin{abstract}
Abstrak
Penelitian ini bertujuan untuk mengetahui penerapan observasi sistematik pada pembelajaran Akidah Akhlaq kelas VII MTs Kedungombo Buaran Mayong Jepara. Penelitian ini menggunakan pendekatan kualitatif deskriptif. Data yang telah terkumpul melalui observasi lapangan dan wawancara dengan sumber data, baik primer maupun sekunder dianalisis dengan tahapan model Miles Huberman. Hasil penelitian menunjukkan bahwa observasi sistematik yang diterapkan di MTs Kedungombo Buaran Mayong Jepara, yakni dengan cara guru mengamati perilaku peserta didik yang telah dipersiapkan kriterianya baik di dalam kelas maupun di luar kelas mulai dari kedisiplinan, tanggungjawab, tenggang rasa, perhatian dan kerajinan sehingga mendapat hasil pembelajaran yang baik. Dengan dilaksanakannya observasi sistematik, guru menjadi lebih aktif dan mengenal karakter serta sikap peserta didik. Di samping itu, peserta didik akan merasa lebih diperhatikan oleh gurunya.
\end{abstract}

Kata Kunci: observasi sistematik, aqidah akhlaq, perilaku peserta didik 


\begin{abstract}
THE APPLICATION OF SYSTEMATIC OBSERVATION ON LEARNING AQIDAH AKHLAQ. This research aims to know the application of systematic observation on Aqidah Akhlaq Lesson in Class VII of MTs Kedungombo Buaran Mayong, Jepara. This research uses qualitative descriptive approach. The data that has been collected through field observation and interview with both of the primary and secondary sources were analyzed with the model of Miles Huberman. The results showed that systematic observation applied in MTs Kedungombo Buaran Mayong Jepara, it was with the way the teacher observes the behavior of learners who have prepared the criteria both in class and outside class ranging from discipline, responsibility, tolerance, thoughtfulness and diligence so that it gets a good learning results. By applying the systematic observations, teacher became more active and get to know the characters and attitudes of learners. Besides, learners will feel more noticed by her teacher.
\end{abstract}

Keywords: systematic observation, aqidah akhlaq, the behaviour of learners

\title{
A. Pendahuluan
}

Penilaian non-test merupakan penilaian yang di gunakan untuk mengukur keberhasilan peserta didik dalam menyerap pelajaran dengan menggunakan alat penilaian nontes ini yakni berupa observasi (pengamatan) teknik bisa digunakan setiap saat pada peserta didik tanpa peserta didik merasa dinilai, namun penilaian ini belum berjalan maksimal dan belum bisa diterapkan secara menyeluruh oleh madrasah-madrasah. Penilaian non tes terdiri dari berbagai macam alat diantaranya observasi, skala bertingkat, kuesioner, wawancara, daftar cocok, dan riwayat hidup. Alat penilaian ini saling melengkapi dan berkaitan satu sama lain.

Penerapan observasi sistematik di MTs Kedungombo telah lama dilakukan yakni mulai tahun 2008 hingga sekarang telah melalui berbagai tahap dalam menilai program tersebut, adanya kendalakendala dalam melakukan observasi sistematik dapat diselesaikan bersama melalui rapat bulanan yang dilakukan sebagai koordinasi antara penilai.

Penerapan observasi sistematik dimulai dari guru piket berada 
di depan pintu gerbang sejak pagi hari untuk mengamati peserta didik yang berangkat ke madrasah, guru piket mengecek kelengkapan dan kedisiplinan peserta didik yang berangkat ke madrasah, kemudian jika ditemukan peserta didik yang kurang disiplin maka guru piket akan menindaklanjuti dengan cara menegur, kemudian jika peserta didik sudah melanggar beberapa kali maka akan diambil kebijakan oleh guru, sedangkan di dalam kelas guru mengamati peserta didik mulai awal pelajaran sampai akhir pelajaran dan jika menemukan sikap peserta didik yang sesuai dengan indikator maka guru akan menilainya.

MTs yang memiliki 12 kelas dengan jumlah peserta didik 519 dan memiliki 40 guru baik honorer maupun guru tetap serta memiliki 2 lantai tersebut sangat memperhatikan perilaku sehari-hari peserta didik (akhlaq), para guru mengamati betul peserta didiknya mulai dari kedisiplinan, sosial dengan teman maupun lingkungan, serta akhlaq pada gurunya, bahkan memiliki kebijakan pemisahan kelas antara peserta didik laki-laki dan perempuan, dengan maksud kenakalan peserta didik laki-laki di kelas dapat diminimalisir. Berdasarkan uraian latar belakang tersebut, penelitian merumuskan beberapa permasalahan, bagaimana penerapan observasi sistematik pada pembelajaran Aqidah Akhlaq di MTs Kedungombo Buaran Mayong Jepara dan apa faktor pendukung dan penghambat penerapan observasi sistematik pada pembelajaran Aqidah Akhlak di MTs Kedungombo Buaran Mayong Jepara.

Penelitian dengan pendekatan kualitatif deskriptif, agar dapat memperoleh data sebanyak-banyaknya yakni dengan cara mendeskripsikan persiapan guru sebelum melakukan kegiatan observasi sistematik pembelajaran Aqidah Akhlaq kelas VII, mendeskripsikan cara membuat kriteria yang akan dinilai, waktu dan tempat terjadinya kegiatan peserta didik diamati secara alamiah, dan mendeskripsikan hasil observasi sistematik yang dilakukan oleh guru dalam bentuk narasi setelah data tersebut dikumpulkan.

Pengumpulan data merupakan langkah yang paling penting dalam penelitian, karena tujuan utama dari penelitian adalah mendapatkan data (Sugiono, 2012: 308) dengan menngunakan metode sebagai berikut: 1) metode observasi (pengamatan), ditujukan 
pada kegiatan guru kepada peserta didik terkait observasi sistematik pada pembelajaran Aqidah Akhlak, pembuatan indikator yang akan dinilai, cara menilai peserta didik, pengamatan guru terhadap perilaku peserta didik baik di kelas maupun di luar kelas selama jam sekolah; 2) metode interview (wawancara), dengan informan kepala MTs, guru Aqidah Akhlaq, dan peserta didik MTs Kedungombo terkait akhlak dalam berinteraksi dengan guru dan teman, baik di dalam kelas maupun di luar kelas; 3) metode dokumentasi, berupa keterkaitan dengan pengajaran guru dikelas antara lain; silabi, program semester, standar kompetensi, kompetensidasar, indikatorpenilaian, rencana pelaksanaan pembelajaran (RPP), daftar nilai chek list hasil observasi sistematik atau skala bertingkat.

Menurut Miles dan Huberman, (1992: 20) mengemukakan bahwa aktivitas dalam analisis data kualitatif dilakukan secara interaktif dan berlangusng secara terus menerus sampai tuntas sehingga datanya sudah jenuh. Setelah data terkumpul analisis data dilakukan dengan beberapa tahap, yaitu: 1) data reduction (reduksi data), halhal pokok yang berkaitan dengan observasi sistamatik pembelajaran Aqidah Akhlaq tersebut adalah perencanaan pembelajaran, proses pembelajaran, dan penilaian nontes dilakukan dengan cara observasi sistematik baik di kelas maupun di luar kelas, 2) data display (penyajian data), mulai dari persiapam administrasi sebelum melakukan observasi sistematik yaitu dengan merumuskan silabi kemudian diturunkan menjadi standar kompetensi (SK), kompetensi dasar (KD), kemudian guru membuat indikator yang akan digunakan pada saat observasi sistematik, setelah persiapan sudah selesai kemudian pada tahap pelaksanaan guru mengamati sikap peserta didik yang masuk dalam kriteria penilaian atau indikator penilaian baik di dalam kelas maupun di luar kelas dihubungkan dengan pelaksanaan observasi sistematik baik di kelas maupun di luar kelas, setelah itu dilakukan pencatatan hasil nilai dari hasil observasi, 3) conclusion drawing (verifikasi), mencari jawab atas rumusan masalah mengenai penerapan observasi sistematik pada pembelajaran Aqidah Akhlak di MTs Kedungombo Buaran Mayong Jepara serta faktor pendukung dan penghambatnya. 


\section{B. Pembahasan}

\section{Evaluasi Pembelajaran}

Kecenderungan yang ada sampai saat ini disekolah adalah bahwa guru hanya menilai prestasi belajar aspek kognitif atau kecerdasan saja. Alatnya adalah tes tertulis. Aspek psikomotorik, apalagi afektif, sangat langka dijamah oleh guru. Akibatnya dapat kita saksikan, yakni pada lulusan hanya menguasai teori tetapi tidak terampil mengerjakan keterampilan. Juga tidak mampu mengaplikasikan pengetahuan yang mereka kuasai. Lemahnya pembelajaran dan evaluasi terhadap aspek afektif ini, jika kita mau intropeksi, telah berakibat merosotnya akhlak para lulusan, yang selanjutnya berdampak pada merosotnya akhlak bangsa (Arikunto: 2002: 20-22).

\section{a. Penilaian nontes}

Teknik penilaian nontes berarti melaksanakan penilaian pada pembelajaran dengan tidak melakukan tes, tatapi menilai kepribadian anak secara keseluruhan yang meliputi aspek kognitif, afektif, dan psikomotorik (Putra, 2013: 138). Penilaian non tes bersifat luas yang mampu memberikan keterangan tentang hasil belajar peserta didik melalui:

1. Observasi, atau pengamatan adalah suatu tehnik penilaian non-tes yang dilakukan secara langsung terhadap peserta didik dengan memperlihatkan tingkah lakunya (Putra, 2013: 138). Ada 3 macam observasi: observasi partisipan, observasi sistematik, dan observasi eksperimental.

2. Wawancara (interview), adalah cara menghimpun berbagai bahan keterangan yang dilaksanakan dengan melakukan Tanya jawab lisan secara sepihak, berhadapan muka, serta dengan arah dan tujuan yang telah ditentukan (Putra, 2013: 145). Wawancara dapat dilakukan dengan dua cara, yaitu: interview bebas (tidak berstruktur atau tidak terpimpin), dan interview terpimpin (terstruktur)

3. Angket (questionnaire) adalah merupakan suatu daftar pertanyaan-pertanyaan tertulis yang harus dijawab oleh peserta didik yang menjadi sasaran dari questionnaire tersebut, ataupun orang lain (Slameto, 2001: 128). 
4. Daftar cocok (chek list) adalah salah satu alat/pedoman observasi yang berupa daftar kemungkinan-kemungkinan aspek tingkah laku seseorang yang sengaja dibuat untuk memudahkan mengenai ada tidaknya aspek-aspek tingkah laku tertentu pada seseorang yang akan dinilai. Orang yang melakukan chek-list tinggal menberi tanda cek $(\sqrt{ })$ pada aspekaspek tingkah laku yang ada pada orang lain atau pada dirinya sendiri. Dan siapa orangnya yang mencek $(\sqrt{ })$ itu tergantung pada jenis /macam daftar cek, bisa guru atau peserta didik sendiri. Guru menilai hasil peserta didik dengan memberikan tanda cek $(\sqrt{ })$ atau silang $(X)$, disamping ciri yang diamati dalam rangka tingkah laku atau hasil pekerjaan yang sedang diamati (dinilai) (Slameto, 2001: 96).

5. Skala Bertingkat, menggambarkan suatu nilai dalam bentuk angka. Angka-angka diberikan secara bertingkat dari angka terendah sampai angka paling tinggi, kemudian angka-angka tersebut dapat digunakan untuk melakukan perbandingan terhadap angka lainnya (Putra, 2013: 159).

6. Riwayat hidup adalah evaluasi mengenai kemajuan peserta didik atau objek yang diteliti dengan cara pemeriksaan terhadap berbagai dokumen (Slameto, 2001: 157).

\section{b. Observasi Sistematik Pembelajaran Aqidah Akhlaq}

Observasi Sistematik, yaitu observasi di mana faktor-faktor yang diamati sudah terdaftar secara sistematis dan sudah diatur menurut katagorinya. Berbeda dengan observasi partisipan, maka dalam observasi sistematik ini pengamat berada diluar kelompok. Dengan demikian maka pengamat tidak dibingungkan oleh situasi yang melingkungi dirinya (Arikunto, 2002: 30). Observasi sistematik merupakan bagian dari instrument evaluasi non tes yang menggunakan table/daftar yang akan dinilai, observasi ini cocok digunakan untuk menilai afektif peserta didik secara terstruktur, agar guru tidak dibingungkan oleh situasi dan kondisi peserta didik ketika menilai.

Observasi sistematik (systematic observation) disebut juga observasi berstruktur, ciri pokok observasi ini adalah adanya kerangka yang memuat faktor-faktor yang telah diatur kategorisasinya lebih 
dahulu, dan ciri-ciri khusus dari tiap-tiap faktor dalam kategorikategori itu, kadang-kadang observasi sistematik menggunakan beberapa macam alat pencatat mekanis (mechanical recording device) seperti film, kamera, tape recorder. Keuntungannya adalah kita dapat memutarnya kembali setiap waktu jika diperlukan sehingga dapat dianalisis lebih lanjut, kelemahannya antara lain membutuhkan biaya yang besar dan tenaga yang professional (Arifin, 2012: 155). Observasi ini sangat luas penggunaannya, bisa melibatkan masyarakat dan orang tua jika ingin memperoleh hasil maksimal disekolah, namun ketika di pondok pesantren observasi ini sangat cocok diterapkan karena sudah terbentuk lingkungan dan sosialnya dapat di-handle oleh kyai dan pengurusnya, dengan demikian observasi akan memperoleh hasil yang maksimal.

Observasi sistematik pembelajaran Aqidah Akhlaq merupakan bentuk penilaian yang dilakukan oleh guru dengan melihat standar kompetensi, kemudian diturunkan dalam kompetensi dasar. Setelah itu guru membuat indikator-indikator penilaian dengan membuat tabel yang berisi beberapa kriteria penilaian baik angka maupun huruf. Selanjutnya, guru mengamati proses pembelajaran keyakinan (aqidah) hubungan dengan Tuhan dan sosial atau hubungan dengan orang lain (akhlaq) peserta didik di kelas, dan diluar kelas selama jam pelajaran perlu diajarkan pada peserta didik mengenai Aqidah dan Akhlaq.

Hal ini sejalan dengan firman Allah dalam surat Luqman ayat 13 yang artinya: "Dan (ingatlah) ketika Luqman berkata kepada anaknya, di waktu ia memberi pelajaran kepadanya: "Hai anakku, janganlah kamu mempersekutukan Allah, sesungguhnya mempersekutukan (Allah) adalah benar-benar kezaliman yang besar." Ayat ini dapat memuat pokok pikiran, pertama, orang tua wajib memberi pendidikan anak-anaknya. Kedua, dalam mendidik prioritas pertama adalah penanaman aqidah, pendidikan aqidah diutamakan agar menjadi kerangka dasar dan landasan dalam membentuk pribadi anak yang sholeh (akhlaqnya).

Tujuan mengajar Aqidah Akhlaq adalah untuk mewujudkan maksud-maksud sebagai berikut:

1. Memperkenalkan kepada murid kepercayaan yang benar yang 
menyelamatkan mereka dari siksaan Allah. Menanamkan dalam jiwa anak beriman kepada Allah, malaikat, kitab-kitab Allah, Rasul-rasul-Nya tentang hari kiamat.

2. Menumbuhkan gnerasi yang kepercayaan dan keimanannya sah dan benar, yang selalu ingat kepada Allah, bersyukur beribadah kepada-Nya.

3. Membantu murid agar berusaha memahami berbagai hakikat misalnya:

a. Allah berkuasa dan mengetahui segala sesuatu

b. Percaya bahwa Allah adil, baik didunia maupun di akhirat

c. Membersihkan jiwa dan pikiran murid dari perbuatan syirik (Mubasyaroh, 2008: 35).

Fungsi observasi sistematik disini yaitu agar memudahkan guru dalam menilai hasil pembelajaran dengan membuat indikatorindikator mengenai sikap berkaitan dengan pelajaran Aqidah Akhlaq Kelas VII yakni dengan merumuskan kompetensi inti Madrasah Tsanawiyah kelas VII observasi sistematik dilakukan dengan membuat tabel yang berisi penjabaran dari kompetensi inti kemudian guru membuat indikator mengenai penilaian yang akan dinilai oleh guru terutama pengampu mata pelajaran Aqidah Akhlaq.

2. Historisitas observasi sistematik pada pembelajaran Aqidah Akhlaq di MTs. Kedungombo Buaran Mayong Jepara.

Observasi dalam pembelajaran di MTs Kedungombo sangat diperhatikan, awalnya peserta didik laki-laki dan perempuan dijadikan satu dalam satu ruangan, namun adanya peserta didik laki-laki yang sering mengganggu peserta didik perempuan, adanya kasus pacaran, dan serta saran dari orang tua untuk memisahkan kelas antara peserta didik laki-laki dan perempuan akhirnya pada tahun 2008 dipisahkan kelas mereka, setelah itu permasalahan sudah terkurangi, namun masih ada permasalahan yang terkadang menyulitkan guru untuk menilai aspek afektifnya, selama satu tahun, kemudian untuk mengukur perkembangan peserta didik maka pengamatan tersebut dikembangkan menjadi observasi sistematik pada tahun 2010, dimana guru mempersiapkan kriteria yang akan dinilai, dan yang belum berubah sikapnya maka diambil kebijakan. Dengan demikian permasalahan yang selama ini dihadapi oleh guru dan orang tua 
karena sikap yang tidak tertata, akhirnya dapat terkurangi meskipun masih ada beberapa hal yang harus dilengkapi.

Dari kajian penelitian ini didapatkan beberapa hal diantaranya:

a. Muatan Observasi Sistematik di Tata Tertib MTs Kedungombo Buaran Mayong Jepara, meliputi:

1. Kehadiran peserta didik, ditandai dengan bel tanda masuk pukul 07.00 WIB, untuk menghindari keterlambatan yang masuk dalam salah satu indikator dalam observasi sistematik maka MTs Kedungombo menganjurkan dalam tata tertib poin pertama yaitu "Berada di Madrasah 10 menit sebelum bel tanda masuk berbunyi”.

2. Saat belajar mengajar, observasi sistematik dilakukan sesuai dengan tata tertib Madrasah baik di dalam kelas maupun di luar kelas, di dalam kelas pada saat pembelajaran berlangsung tertera pada poin pertama tata tertib pada saat belajar mengajar yakni "Peserta didik dilarang becanda, membuat gaduh/ onar atau mengganggu ketertiban KBM", dan pada poin ke empat "Wajib mengikuti tadarus dan berdo'a pada awal dan akhir jam pelajaran" serta pada poin ke lima "Mengerjakan tugastugas yang diberikan oleh guru" yang masing-masing masuk dalam indikator perhatian, dan disiplin. kemudian diluar kelas yang masuk pada poin terakhir yakni "Keluar dari lingkungan MTs Kedungombo harus seizin guru piket” guru piket pada saat jam pelajaran sudah berada di depan kantor guru untuk mengobservasi peserta didik.

3. Etika dan estetika, pembelajaran Aqidah Akhlak pada dasarnya mengacu pada tujuan pokok ajaran islam dan NKRI, hal ini sesuai dengan tata tertib pada poin pertama "Selalu menjunjung tinggi dan mengamalkan ajaran islam serta moral pancasila" serta "Selalu bersikap sopan santun, jujur kepada orang tua, guru, karyawan, sesama teman dan masyarakat" hasil dari pembelajaran yang diukur melalui observasi sistemati tentunya mengarah pada dua tujuan besar diatas dan pada poin terakhir yang tercantum pada indikator disiplin observasi sistematik yakni "Mengamalkan 
$4 \mathrm{~T}$ (tertib waktu, tertib belajar, tertib lingkungan dan tertib adminstrasi)".

4. Kegiatan ibadah, merupakan bentuk dari implementasi akidah kemudian diwujudkan dalam bentuk akhlak kepada alam sekitar, selaras dengan implementasi do'a-do'a dan sholat yang terkandung dalam kegiatan di MTs Kedungombo yang masuk pada penilaian observasi sistematik pada ranah perhatian dan tanggungjawab sebagai seorang muslim, yakni:

a. Mengikuti shalat Dhuha sesuai dengan jadwal yang telah ditentukan

b. Shalat Dhuhur berjama'ah

c. Membaca asma'ul husna setelah do'a pagi

d. Membaca surat al-Fatihah atau ayat pendek yang telah ditentukan sebelum mulai mata pelajaran.

e. Menutup kegiatan KBM dengan berdo'a kafarotul majelis.

5. Larangan, di mana observasi sistematik pada dasarnya juga mengacu pada tata tertib mengenai larangan yang mana ketika peserta didik membuat keonaran atau memiliki pelanggaran diluar batas seperti pada poin ke 11 "Dilarang membuat keonaran/kegaduhan, tawuran, berkelahi, dan membuat kerusuhan di lingkungan maupun di luar MTs Kedungombo" maka ada tahapan dalm memberi sanksi atau hukuman yakni:

a. Peringatan secara lisan.

b. Peringatan melalui penugasan (bidang akademik atau kebersihan lingkungan).

c. Peringatan secara tertulis.

d. Skorsing.

e. Dikeluarkan atau dikembalikan pada orang tua/wali.

Observasi sistematik yang salah satunya dirumuskan melalui tata tertib tersebut bermaksud agar peserta didik mampu bersikap disiplin dan mentaati tata tertib yang menjadi kebijakan dari MTs Kedungombo. 


\section{b. Penerapan Observasi Sistematik Pembelajaran Aqidah Akhlaq Kelas VII di MTs Kedungombo Buaran Mayong Jepara}

Sebelum melakukan observasi sistematik peneliti mempersiapkan administrasi untuk melakukan observasi sistematik, seperti yang diungkapkan oleh Nailul Huda, selaku guru piket dan guru BK, Persiapan administrasi dimulai dari rumusan visi dan misi, kemudian tata tertib, dari kompetensi inti, kompetensi dasar, dan di hubungkan dengan kriteria penilaian yang disiapkan oleh madrasah dengan perangkat keras berupa komputer, meja dan kursi yang dipersiapkan di depan kantor guru, lembar penilaian, setelah administrasi sudah dipersiapkan maka dilakukanlah observasi tersebut.

Observasi sistematik MTs Kedungombo yang dilakukan di luar kelas dimulai sejak pagi hari ketika peserta didik berangkat Madrasah, guru piket sudah didepan gerbang untuk mengamati peserta didik yang baru datang, selaku guru piket beliau berkata bahwa pada dasarnya menilai sikap peserta didik yang dirumuskan ke dalam 5 aspek yaitu: 1) disiplin baik pakaian/ seragam maupun disiplin waktu berangkat; kemudian 2) tanggungjawab ketika peserta didik melanggar tata tertib Madrasah; 3) perhatian maksudnya adalah tingkat responnya ketika mendengar bel masuk atau ada pengumuman untuk berjamaah; 4) kerajinan maksudnya adalah kerajinan peserta didik untuk mengikuti kegiatan Madrasah dengan tekun; 5) tenggang rasa mengenai hubungan dengan teman dan guru, pelaksanaannya dimulai dari pagi hari guru sudah berada di depan pintu gerbang untuk mengamati peserta didik, dan guru piket setelah itu berada di depan kantor guru untuk mengamati peserta didik yang keluar masuk Madrasah. Observasi sistematik di dalam dan diluar kelas memiliki tehnik yang berbeda, guru piket melaksanakan observasi sistematik, sejak pagi sudah didepan gerbang untuk mengecek peserta didik yang kurang disiplin, baik keberangkatan, cara berpakaian, pada saat jamaah sholat Dhuhur, peran guru piket di bantu oleh dua orang guru BK, dan masing-masing memegang 259 anak dari 519 peserta didik, guru BK harus hafal nama peserta didik, atau minimal mengenal wajah dan alamatnya, guru BK membantu menyelesaiakan persoalan-persoalan yang menghambat belajar peserta didik. 
Seorang wali kelas VII D menyatakan bahwa guru membuat lembaran kertas yang berisikan tentang kriteria yang akan dinilai kemudian guru mengamati peserta didik, kemudian sikap peserta didik yang masuk dalam kriteria akan dinilai dengan ketentuan yang telah ditentukan. Dengan demikian guru akan mudah menilai peserta didik dengan angka yang di tentukan. Peserta didik sebagai objek observasi memiliki tanggapan mengenai observasi yang dilakukan oleh pihak madrasah, diantanya seorang peserta didik kelas VII A, ketika ditanya mengenai kedisiplinan berangkat ke Madrasah tepat waktu menjawab, bahwa Sebagian peserta didik tepat waktu dan sebagian tidak, namun yang terlambat hanya sedikit dan itupun jarang, begitu pula yang diungkapkan oleh Rima Firdayasa kelas VII B, bahwa peserta didik perempuan berangkat tepat waktu, paling hanya sedikit yang telat karena alasan tertentu. Hal ini senada dengan peserta didik kelas VII C yang juga menegaskan bahwa hanya sedikit peserta didik yang terlambat. Begitu juga mengenai kerapian dan sikap saat bertemu dengan guru mereka bersalaman, memberi salam dan jika di depan guru mereka merunduk.

Pertemanan antar peserta didik juga baik, sering becanda dan barmain bersama, seperti yang diungkapkan oleh peserta didik kelas VII B, bahwa persahabatan mereka diwarnai dengan canda, bermain, jajan bareng. Peserta didik yang lain juga mengungkapkan hampir sama ada yang cara becandanya memakai pukulan, saling mendorong dan lainnya.

Persiapan administrasi dimulai dari perumusan standar kompetensi kemudian kompetensi dasar, oleh seorang guru aqidah akhlaq kemudian membuat kriteria penilaian atau indikator yang akan dinilai dan perangkat yang digunakan berupa laptop untuk membuat administrasi tersebut, kemudian pada tahap pelaksanaan observasi sistematik saat mulai pelajaran sampai akhir pelajaran, karena ini mencangkup sikap peserta didik, kadang di tengah pelajaran ada yang mengganggu teman, kurang disiplin, itu kami nilai, namun saat diskusi guru juga bisa menilai karakter peserta didik, baik dari kerjasama, tenggang rasa, perhatian terhadap diskusi, sehingga guru dapat mengetahui karakter peserta didiknya.

Kepala MTs menambahkan bahwa observasi sistematik di MTs Kedungombo digunakan untuk mengukur perilaku peserta 
didik yang mana harus mengacu pada visi dan misi Madrasah yang salah satunya "Menginternalisasikan nilai-nilai akhlaqul karimah dalam kehidupan sehari-hari" dan observasi ini sangat membantu dalam mengukur kemampuan spiritual peserta didik, dan dengan observasi sistematik diharapkan guru mampu memahami dan mengerti sebatas mana penyampaian yang dilakuakan pada saat pembelajaran, sehingga bisa juga digunakan guru dalam mengevaluasi diri. Kebijakan Kepala MTs sebagai supervisor dalam mengevaluasi peserta didiksangat bijak yakni dengan mengintruksikan semua guru dan karyawan MTs Kedungombo saling bekerjasama dalam mensukseskan pendidikan di MTs tersebut dengan demikian guru menjadi tidak begitu kerepotan meskipun masing-masing memiliki tugas pokok dan fungsi yang berbeda-beda sesuai dengan jebatan yang didapatkan, Mustaidi, selaku wali kelas VII D juga menyatakan bahwa untuk membuat kebijakan diadakan rapat setiap satu bulan sekali sebagai koordinasi atas keluhan guru, dan kebijakannya adalah kerjasama guru dalam menangani peserta didik yang baik, untuk masalah penilaian sesuai dengan KKM yang ditentukan.

\section{c. Faktor pendukung dan penghambat penerapan observasi sistematik pada Pembelajaran Aqidah Akhlaq di MTs Kedungombo Buaran Mayong Jepara.}

Observasi sistematik pada pembelajaran aqidah akhlaq melibatkan guru piket, di bantu oleh 2 orang guru BK, masing-masing memegang 259 anak dari sekitar 519 peserta didik, yang mana guru BK harus hafal nama peserta didik, atau minimal mengenal wajah dan alamatnya, guru BK membantu menyelesaiakan persoalan-persoalan yang menghambat belajar peserta didik. Selain hal tersebut peralatan administrasi seperti laptop, computer juga sebagai alat pendukung dalam membuat nilai secara otomatis sehingga kerja guru dalam menilai menjadi lebih mudah baik observasi didalam kelas maupun diluar kelas.

Faktor pendukung lainnya adalah kerjasama antar guru untuk melakukan observasi sistematik, 400 orang tua peserta didik yang mensuport, peserta didik perempuan terbuka dalam menceritakan masalahnya, adanya computer untuk membuat administrasi dan penilaian secara otomatis. Selain itu orang tua peserta didik juga 
sangat menghormati keputusan dari Madrasah dan mendatangi undangan Madrasah jika anak-anak mereka melakukan pelanggaran yang mengharuskan orang tuanya dipanggil oleh pihak Madrasah.

Observasi sistematik juga memiliki faktor-faktor penghambat, seperti yang dijelaskan oleh seorang guru mata pelajaran Aqidah Akhlaq MTs Kedungombo Buaran adalah guru terlalu banyak tugas apalagi guru perempuan yang harus mengurus kebutuhan di rumah, kemudian waktu yang terlalu singkat untuk menjelaskan dan mengobservasi. Guru ynag lain juga menambahkan bahwa penghambat dalam observasi sistematik di luar kelas adalah peserta didik laki-laki jika mengalami masalah jarang terbuka, keterbatasan waktu, dalam mengamati, soalnya guru memiliki tugas ganda selain sebagai guru BK, guru piket, dan Waka Kurikulum.

Data yang telah dianalisis dipaparkan sebagai berikut:

1. Penerapan Observasi Sistematik Pembelajaran Aqidah Akhlaq Kelas VII di MTs Kedungombo Buaran Mayong Jepara

Domain afektif manjadi hal yang sangat penting dalam pendidikan, karena hasil dari pendidikan adalah perubahan sikap maka perlu adanya perhatian yang lebih terhadap ranah afektif, hal ini sangat berkaitan erat dengan pelajaran Aqidah Akhlaq, karena Akidah dan Akhlak merupakan inti pokok ajaran Islam, yakni dengan cara meyakini adanya Allah sebagai iman sehingga akan memunculkan dorongan dari diri seorang peserta didik untuk bersikap baik dan taat pada ajaran agama Islam, sedangkan akhlak memberikan tata aturan yang baik dalam berhubungan social kemasyarakatan dengan sesama manusia, sehingga terciptalah keselarasan antara kebutuhan batin dan lahirnya yang akan menciptakan kedamaian dan kebijaksanaan.

Observasi sistematik yang dilakuakan guru MTs Kedungombo memberikan dampak positif bagi pembelajaran, dengan adanya observasi sistematik guru mampu mengenal lebih jauh karakter murid dan bisa memantau perkembangannya setiap hari, terbukti dengan peserta didik yang mampu berdo'a dengan baik dan khusyu' dan sedikit pelanggaran yang dilakukan oleh peserta didik, persahabatan yang baik, sikap betemu dengan guru, hal ini menandakan bahwa MTs Kedungombosudah lebih maju dalam menanamkan karakter baik pada peserta didiknya, meskipun ada kekurangan yang harus 
dibenahi. Observasi sistematik yang dilakukan di luar kelas untuk mengetahui sikap peserta didik sudah dijalankan guru sesuai dengan aturan, untuk mengukur, guru mempersiapkan skala pengukuran yang dirumuskan dari visi dan misi Madrasah, dan standart kompetensi serta kompetensi dasar, dan cara yang dilakukan guru adalah ketika pagi hari peserta didik berangkat ke madrasah dalam keadaan kerapian yang berbeda-beda, ada yang bajunya keluar, ada yang telat, dan ada pula yang rapi, guru piket sebagai pelaksana observasi sistematik tersebut di bantu oleh guru BK untuk mengetahui namanama peserta didik yang belum diketahui nama dan karekternya, jika terlalu berat pelanggarannya maka guru BK yang menangani dan dibantu oleh wali kelas.

Pelaksanaan observasi sistematik di luar kelas juga dilakukan guru piket selama jam efektif madrasah berlangsung, guru berada di luar ruang guru yang letaknya di samping gerbang pintu utama keluar masuk peserta didik, dan disana guru tersebut memperhatikan peserta didiknya mulai cara berpakaian dan waktu ketepatan dalam masuk kelas yang terhimpun dalam aspek disiplin, serta sosial dengan teman, ketika bertemu dengan guru dan lainnya yang ada dalam kertas observasi sistematik yang sudah disediakan guru berupa skala penilaian. Skala bertingkat menggambarkan suatu nilai dalam bentuk angka. Angka-angka diberikan secara bertingkat dari angka terendah sampai angka paling tinggi. Kemudian angka-angka tersebut dapat digunakan untuk melakukan perbandingan terhadap angka lainnya. skala ini bertujuan agar guru tidak kebingungan dalam menatapkan nilai terandah dan tertinggi sehingga guru dapat mengetahui hasil belajar peserta didik, mana yang memperoleh nilai tinggi, sedang dan terendah.

Observasi sistematik yang dilakukan di dalam kelas juga menggunakan skala bertingkat atau daftar cek, dalam pelaksanaanya guru melakukan mulai dari awal pembelajaran sampai akhir pembelajaran Aqidah Akhlaq, aspek yang dinilai adalah tinggkat keyakinan peserta didik bisa dilihat melalui cara dia berdoa, mendengar adzan, dan respon ketika disuruh sholat, serta mampu menghafal bacaan sholat dan melaksanakannya dibuktikan dengan pengakuannya, kemudian guru menilai dari cara bersosial dengan teman, aspek perhatian ketika guru sedang menjelaskan, dan hasil 
dari observasi sistematik tersebut jika mengalami permasalahan pada diri peserta didik maka ada evaluasi yang dilaksanakan pihak guru setiap satu bulan sekali, dan hal ini tentu saja menjadi solusi karena antara guru yang mengampu mata pelajaran Aqidah Akhlaq berdiskusi dengan guru BK dan wali kelas yang mengetahui karakter dan latar belakang peserta didik masing-masing.

Observasi sistematik yang diterapkan di MTs Kedungombo baik didalam maupun diluar kelas pada dasarnya selalu mengarah pada Akhlak atau moral peserta didik agar menjadi lebih baik. Guru sudah melaksanakan sebaik mungkin dalam menangani persoalan Aqidah dan Akhlaq, hasilnya cukup bagus terbukti yang kelas VIII dan IX berhasil mampu membawa nama MTs Kedungombo familiar di tingkat desa maupun dikecamatan. Sehingga para orang tua menaruh kepercayaan yang besar di MTs tersebut hingga memiliki murid sampai 519 peserta didik, dan itupun bisa lebih jika sudah terdapat ruang yang memadai.

Moral memang menjadi hal pokok dalam hasil belajar, khususnya pembelajaran Aqidah Akhlaq yang memang harus meyakini keberadaan Allah yang maha mengawasi, dan diimplementasikan dalam bentuk Akhlaq, baik kepada manusia maupun mahluk Allah yang lain, dengan adanya penilaian sikap maka guru dapat mengetahui karakter peserta didik dan jika ada peserta didik yang masih tetap melakukan pelanggaran maka akan ditangani lebih lanjut oleh buru BK dan wali kelas dengan berbagai pertimbangan.dalam hal ini MTs Kedungombo menerapkan sistem evaluasi dengan observasi sistematik agar lulusan dari MTs tersebut dapat memberikan kontribusi yang positif terhadap moral masyarakat.

Observasi sistematik di MTs Kedungombo selalu dibidik dan diselesaikan bersama apabila menemui suatu habatan, seperti yang disampaikan kepala MTs, dengan administrasi yang baik dan tata kelola yang baik maka MTs ini menjadi magnet untuk menarik peserta didik disekitar daerah utara Mayong.

2. Faktor pendukung dan penghambat penerapan observasi sistematik pada Pembelajaran Aqidah Akhlaq di MTs Kedungombo Buaran Mayong Jepara

Melihat proses kegiatan ini dilakukan oleh guru baik di 
dalam kelas maupun di luar kelas, didalam kelas guru Aqidah Akhlaq selalu mengamati peserta didik mulai awal pelajaran sampai akhir dan guru banyak yang terlibat dalam hal ini, guru piket, guru BK, Kepala MTs, serta pegawai yang lain ikut serta dalam mensukseskan observasi sistematik. Observasi yang melibatkan segenap guru yang bekerjasama dalam mengevaluasi hasil pembelajaran yang telah dilakukan oleh guru, dengan teknik, model dan metode yang berbeda-beda sesuai dengan apa yang dibutuhkan, serta peran orang tua sebagai pembimbing peserta didik ketika di rumah juga berperan aktif ikut memperhatikan anak-anaknya dalam hal belajar dan kesehariannya, bahkan orang tua peserta didik sebagian besar selalu menghadiri panggilan dari Madrasah jika anak-anaknya mengalami suatu pelanggaran berat, orang tua selalu berharap bahwa anaknya dapat menjadi anak yang berbakti kepada kedua orang tua, mengetahui tentang agama dan lain sebagainya, dengan demikian madrasah membuat berbagai macam ektrakulikuler yang dapat digunakan peserta didik sebagai ajang mengembangkan bakat dan minatnya.

Hal tersebut di atas menjadi pendukung dalam pelaksanaan observasi sistematik. Sebagaimana pernyataan guru mata pelajaran Aqidah Akhlaq yang menyatakan bahwa faktor pendukungnya adalah guru-guru lain saling bekerjasama dalam mengobservasi dan mengingatkan peserta didik yang kurang disiplin, juga ikut memberikan motivasi pada peserta didik, adanya laptop untuk melengkapi administrasi dan secara otomatis menyajikan nilai.

Kepala MTs selaku supervisor juga selalu memantau kinerja guru dan karyawan agar selalu bekerja dengan disiplin, setiap pagi setelah bel berbunyi Kepala Madrasah selalu berkeliling ke kelas-kelas untuk mngecek kedisiplinan, kebersihan dan kerapian peserta didik dan ruangannya, serta ke-khusyu'an dalam berdo'a dan membaca asmaul husna, jika menemukan peserta didik yang kurang disiplin maka KepalaMadrasah akan menghukum dengan membersihkan ruangan atau halaman, atau disuruh istighfar dan menulisnya sebanyak 1000 kali.

Administrasi yang telah dipersiapkan dengan peralatan laptop dan printer yang disediakan juga menjadi pendukung dalam 
pelaksanaan observasi sistematik, selain guru sebagai observer dalam kegiatan ini, adanya rapat rutin setiap bulan mengenai permaslahan evaluasi, sistem pengajaran, tata usaha dan lainnya menjadikan setiap permasalahan terasa ringan meskipun masih ada beberapa kekurangan. Guru memandang observasi sistematik ini bagus diterapkan karena beberapa kelebihannya yang antara lain:

a. Data observasi itu diperoleh secara langsung dilapangan, yakni dengan jalan melihat dan mengamati kegiatan atau expresi peserta didik didalam melakukan sesuatu, sehingga dengan demikian data tersebut lebih bersifat obyektif dalam melukiskan aspek-aspek kepribadian peserta didik menurut keadaan yang senyatanya.

b. Data hasil observasi dapat mencakup berbagai aspek kepribadian masing-masing individu peserta didik, dengan demikian maka didalam pengolahannya tidak berat sebelah atau hanya menekankan pada salah satu segi saja dari kecakapan atau prestasi belajar mereka.

Penerapan observasi sistematik pada pembelajaran Aqidah Akhlaq di MTs Kedungombo Buaran juga memiliki hal yang menghambat baik dari pribadi observer maupun administrasinya, faktor kekurangannya adalah guru juga memiliki kesibukan merawat anak dan sebagai seorang istri jadi harus menyesuaikan antara tugas Madrasah dan tugas rumah tangga, tugas madrasah yang banyak terkadang membuat guru tidak bisa menyesuaikan antara kedua kebutuhan tersebut, jika didalam kelas guru juga harus menjelaskan dan mengobservasi peserta didik pada waktu yang bersamaan, namun ketika diberi tugas atau diskusi guru dengan mudah mengobservasi.

Faktor kekurangannya adalah guru BK yang bekerjasama dengan guru piket terkadang tidak mengetahui nama peserta didik sehingga guru kesulitan dalam menilai sikapnya, dan bagi guru yang belum hafal nama peserta didiknya waktunya terlalu singkat untuk menilai dengan seksama diluar kelas. Di satu sisi observasi juga memiliki kelemahan yang antara lain: guru yang tidak atau kurang memiliki kecakapan atau keterampilan dalam melakukan observasi, maka hasil observasinya menjadi kurang dapat diyakini kebenarannya. Untuk menghasilkan data observasi yang baik, seorang guru harus mampu membedakan antara apa yang tersurat dengan apa yang 
tersirat. Kepribadian (personality) dari observer atau evaluator juga ancapkali mewarnai atau menyelinap masuk kedalam penilaian yang dilakukan dengan cara observasi. Prasangka-prasangka yang mungkin melekat pada diri observer (evaluator) dapat mengakibatkan sulit dipisahkan secara tegas mengenai tingkah laku peserta didik yang diamatinya. Oleh karenanya observer harus pandai dalam mengamati dengan berbagai sudut pandang yang obyektif sehingga hasil penelitian benar-benar bisa dipertanggung jawabkan.

Data yang diperoleh dari kegiatan observasi umumnya baru dapat mengungkap kulit luarnya saja. Adapun apa-apa yang sesungguhnya terjadi di balik hasil pengamatan itu belum dapat diungkap secara tuntas hanya dengan melakukan observasi saja. Karena itu observasi harus didukung dengan cara-cara lainnya, misalnya dengan melakukan wawancara.oleh karena itu observasi harus dilakukan dengan teliti dan didukung dengan wawancara, dokumentasi dan lainnya agar memperoleh hasil yang obyektif.

Tindak lanjut dalam menangani peserta didik memang harus dilakukan, semua guru harus memperhatikan perkembangan peserta didik dengan baik, hal ini dilakuakn oleh wali kelas yang mana wali kelas berperan dalam menangani peserta didik yang kurang disiplin bekerjasama dengan guru $\mathrm{BK}$, dengan cara pendekatan terhadap peserta didik, kepada orang tua peserta didik agar guru mengetahui persolan yang meyebabkan peserta didik bersikap sedemikian rupa, dengan demikian guru menjadi lebih dekat dengan peserta didik ataupun dengan orang tua, dengan harapan peserta didik dapat belajar dengan nyaman dan tenang.

\section{Simpulan}

Memperhatikan uraian analisis di atas, dapat disimpulkan seperti berikut:

1. Penerapan observasi sistematik yang dilakukan para guru MTs Kedungombo di dalam kelas berawal dari perumusan visi misi Madrasah, tata tertib, prota, promes, silabi, standar kompetetensi ke kompetensi dasar kemudian dirumuskan menjadi indicator-indikator penilaian untuk peserta didik, dan dilaksanakan selama pembelajaran berlangsung, di luar 
kelas guru piket mengamati peserta mulai pagi hari sampai jam pulang sekolah, guru piket berada di depan ruang guru yang berada di samping gerbang, tindak lanjut terhadap peserta didik yang melakukan banyak pelanggaran ditangani oleh guru BK yang bekerjasama dengan wali kelas serta orang tua peserta didik, dengan tahap-tahap tertentu. Dengan observasi sistematik dan pembinaan yang dilakukan oleh guru, peserta didik mampu mengendalikan sifat remaja yang biasanya disebut dengan kenakalan remaja serta mampu bersikap sopan.

2. Faktor pendukungnya mulai dari administrasi yang dikerjakan dengan perangkat modern, kerjasama antar guru mulai dari guru mata pelajaran Aqidah Akhlaq, guru piket, guru BK, wali kelas dan kepala sekolah, orang tua peserta didik yang mendukung penuh kebijakan Madrasah meskipun ada sedikit penghambat yaitu tugas ganda guru yang memiliki jabatan secara struktural dan fungsional, sehingga guru di hadapkan pada dua tugas dalam waktu yang bersamaan. 


\section{Daftar Pustaka}

Hubeman, Miles. 1992, Analisis Data Kualitatif, Jakarta: Universitas Indonesia Press.

Mubasyaroh. 2008. Materi dan Pembelajaran Aqidah Akhlaq. Kudus: Dipa STAIN Kudus.

Sitiatava Rizema Putra. 2013. Desain Evaluasi Belajar Berbasis Kinerja. Yogyakarta: Diva Press.

Slameto. 2001. Evaluasi Pendidikan. Jakarta: Bumi Aksara.

Sugiyono. 2008. Metode Penelitian Pendidikan Pendekatan, Kuantitaif, Kualitatif, dan R \& D. Bandung: Alfabeta.

Sugiyono. 2012. Metode Penelitian Pendidikan. Bandung: Alfabeta.

Suharsimi Arikunto.2002. Dadar-dasar Evaluasi Pendidikan. Jakarta: Bumi Aksara.

Tafsir, Ahmad. 1997. Metodologi Pengajaran Agama Islam. Bandung: Remaja Posdakarya Offset.

Tim Penyusun. 2004. Al-Jumanatul Ali: Al-Qur'an dan Terjemahannya. Bandung: J-Art.

Zainal Arifin. 2012. Evaluasi Pembelajaran. Bandung: Rosda Karya. 
Ismanto dan Eka Fery Irawan

halaman ini bukan sengaja dikosongkan 